\title{
Where do Borders Lie in Translated Literature? The case of the changing English-language market
}

\section{Richard Mansell University of Exeter}

Anecdotal accounts suggest that one reason for the perceived resistance to translated literature in English-language markets is that commissioning editors are averse to considering texts that they cannot read. In an attempt to overcome this barrier, English translations are increasingly commissioned by publishers of source texts and agents of source authors and used to stimulate interest in a book (not just in English-language markets), a phenomenon this article terms 'sourcecommissioned translations'. This article considers how this phenomenon indicates a shift in the borders between literatures, how it disrupts accepted commercial practices, and the consequences of this for the industry and the role of English in the global book trade. In particular, it considers consequences for the quality of translations, questions regarding copyright, and the uncertain position for the translator when, at the time of translating, a contract is not in place between the translator and the publisher of the translation. 